\title{
Penggunaan Heparin Dosis Tinggi pada Pasien COVID-19 dengan ARDS dan Hipertensi di Unit Perawatan Intensif (ICU)
}

\section{Use of High-Dose Heparin in COVID-19 Patients with ARDS and Hypertension in the Intensive Care Unit (ICU)}

\author{
Taufik Eko Nugroho ${ }^{\bowtie}$, Mochamat, Famila \\ Departemen Anestesiologi dan Terapi Intensif, Fakultas Kedokteran, Universitas Diponegoro, \\ Semarang, Indonesia \\ ${ }^{\bowtie}$ Korespondensi: taufik.anestesi@gmail.com
}

\begin{abstract}
Background: Corona Virus Disease 2019 (COVID-19), first reported in December 2019 in China, is a disease caused by the SARS-CoV-2 virus which spreads faster in the human population and in a short time has developed into a worldwide pandemic. Most of the cases that resulted in death reported were complicated by coagulopathy and disseminated intravascular cogulation (DIC).

Case: A 50-year-old man confirmed positive for COVID-19 with breathlessness, cough and fever and hypertensive comorbidities was referred to the intensive care unit (ICU), while in ICU the patient received heparin therapy with therapeutic doses by looking at aPTT levels. After 14 days of intensive care, the patient experienced significant improvement.

Discussion: Patients with progressive and severe COVID-19 infection with acute respiratory distress syndrome (ARDS) often present with very high levels of D-dimer and fibrinogen, leading to a hypercoagulable state. The use of anticoagulants for patients with severe COVID-19 has been. Many institutions have adopted the empiric use of fulldose anticoagulants based on the risk of venous thrombo embolism (VTE) and the low incidence of bleeding (3-5\%).

Conclusion: The use of anticoagulants, especially higher doses of unfractionated heparin (UFH), is recommended for patients with severe COVID-19, although there are no absolute guidelines.
\end{abstract}

Keywords: ARDS; coagulopathy; COVID-19; heparin; VTE 


\begin{abstract}
ABSTRAK
Latar Belakang: Corona Virus Disease 2019 (COVID-19), pertama kali dilaporkan pada bulan Desember 2019 di Cina, merupakan penyakit yang disebabkan oleh virus SARSCoV-2 yang menyebar lebih cepat pada populasi manusia dan dalam waktu singkat berkembang menjadi pandemi di seluruh dunia. Sebagian besar kasus yang berujung pada kematian dilaporkan terkomplikasi dengan koagulopati dan disseminated intravascular cogulation (DIC).
\end{abstract}

Kasus: Seorang laki-laki terkonfirmasi positif COVID-19 berusia 50 tahun dengan sesak, batuk dan demam dan komorbiditas hipertensi dirujuk ke intensive care unit (ICU), selama di ICU pasien mendapat terapi heparin dengan dosis terapi dengan melihat kadar aPTT. Setelah perawatan intensif selama 14 hari, pasien mengalami perbaikan yang signifikan.

Pembahasan: Pasien dengan infeksi COVID-19 yang progresif dan parah dengan acute respiratory distress syndrome (ARDS) seringkali ditemukan dengan kadar D-dimer dan fibrinogen yang sangat tinggi, yang berujung pada keadaan hiperkoagulasi. Penggunaan antikoagulan untuk pasien dengan COVID-19 yang parah telah. Banyak institusi telah menerapkan penggunaan antikoagulan dosis penuh secara empiris berdasarkan risiko venous thrombo embolism (VTE) dan insiden rendah perdarahan (3-5\%).

Kesimpulan: Penggunaan antikoagulan, khususnya unfractionated heparin (UFH) dengan dosis lebih tinggi, direkomendasikan untuk pasien dengan COVID-19 yang parah, meskipun belum ada panduan yang mutlak.

Kata Kunci: ARDS; COVID-19; heparin; koagulopati; VTE

\section{PENDAHULUAN}

Penyakit Corona Virus Disease 2019 (COVID-19) pertama kali dilaporkan pada Desember 2019 di Cina, disebabkan oleh virus SARS-CoV-2 yang sangat erat kaitannya dengan virus corona lain yang muncul sebelumnya seperti SARS- CoV dan MERS - CoV, namun virus ini nampaknya menyebar lebih cepat pada populasi manusia dan dalam waktu singkat menjadi pandemi di seluruh dunia. Kasus ini merupakan penyakit sistemik dengan manifestasi klinis bervariasi dari kondisi asimptomatik sampai pneumonia berat dengan respiratory distress syndrome (ARDS) dan disfungsi organ multipel, dengan komplikasi terburuk yaitu kematian. ${ }^{1,2}$ Sebuah studi epidemiologi skala besar yang dilakukan di China menunjukkan bahwa dari sekitar 45.000 kasus yang terkonfirmasi positif, hanya $4,7 \%$ yang memburuk hingga kondisi kritis, 80,7\% merupakan kasus ringan, dan sisanya 13,8\% merupakan kasus berat. Angka kematian pada kasus kritis ditemukan lebih tinggi pada pasien dengan komorbiditas, seperti penyakit kardiovaskular, diabetes, hipertensi, penyakit napas kronis, dan keganasan. ${ }^{3,4}$

Sebagian besar kasus yang menyebabkan kematian dilaporkan terkomplikasi dengan koagulopati dan disseminated intravascular cogulation (DIC). Ditemukan bahwa kasus COVID-19 dengan infeksi berat dan progresif dengan ARDS memiliki tingkat $D$ Dimer dan fibrinogen yang sangat tinggi, yang berujung pada kondisi hiperkoagulasi. Terapi antikoagulan direkomendasikan untuk diberikan pada pasien terkonfirmasi COVID-19 yang berat hingga kritis, untuk membantu 
mengatasi pembekuan darah yang tidak terkontrol dan mengurangi pembentukan mikrotrombus yang diyakini sebagai etiologi yang mendasari terjadinya disfungsi organ vital. ${ }^{3-5}$ Pada laporan kasus ini, kami mencoba menyajikan sebuah kasus terkonfirmasi COVID-19, seorang laki-laki berusia 50 tahun dengan komorbiditas hipertensi yang mendapat terapi heparin dan menunjukkan perbaikan yang signifikan selama dirawat di intensive care unit (ICU).

\section{KASUS}

Seorang laki-laki berusia 50 tahun datang ke instalasi gawat darurat (IGD) Rumah Sakit Nasional Diponegoro (RSND) dengan keluhan utama berupa sesak napas memberat, batuk, disertai palpitasi, penurunan nafsu makan, dan kelemahan. Tidak ada tanda-tanda penurunan kesadaran. Pasien mengalami demam dan menyangkal kemungkinan kontak dengan pasien COVID-19 yang terkonfirmasi. Pasien memiliki riwayat perjalanan ke luar kota selama 4 minggu terakhir. Pasien mengakui adanya riwayat hipertensi sebelumnya namun pasien tidak pernah mengkonsumsi obat maupun kontrol rutin untuk kondisinya.
Pasien menyangkal adanya riwayat diabetes, asma, serangan jantung, ataupun alergi. Tidak ada anggota keluarganya yang mengalami gejala serupa.

Dari pemeriksaan fisik didapatkan hipertensi stadium II, dengan tekanan darah 174/90 mmHg. Ditemukan juga takikardia ringan dan takipnea, dengan denyut jantung 104 kali per menit dan frekuensi pernapasan 24 kali per menit. Suhu tubuh pasien tidak tinggi. Saturasi oksigen mencapai $97 \%$ diukur pada jari tangan kiri, dengan suplementasi oksigen 3 liter per menit melalui nasal kanul. Dari auskultasi paru, ditemukan ronki bilateral. Pemeriksaan fisik lainnya dari kepala sampai kaki ditemukan dalam batas normal.

Pemeriksaan darah awal ditemukan kadar D-Dimer $4.84 \mathrm{ug} / \mathrm{ml}$. Hasil rapid test COVID-19 pada pasien ditemukan reaktif yang kemudian dikonfirmasi dengan swab polymerase chain reaction (PCR). Temuan laboratorium lainnya dalam batas normal. Dari foto toraks awal pada didapatkan gambaran bronkopneumonia yang diduga karena virus (Gambar 1).

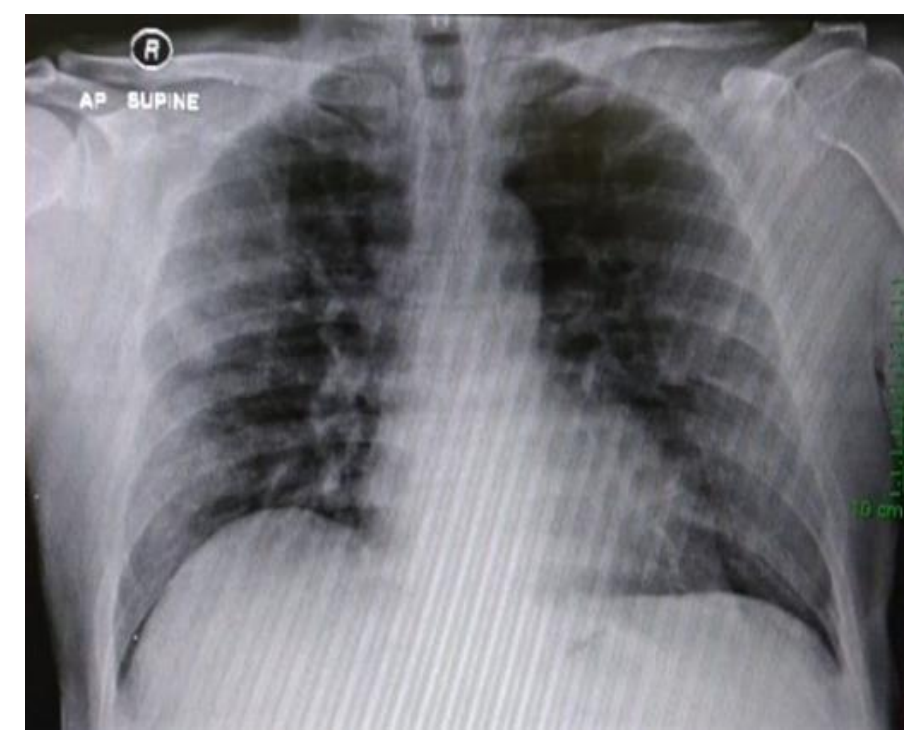

Gambar 1. X-foto toraks hari ke-1 
Pasien dimasukkan ke ICU dengan diagnosis pneumonia COVID-19 dan hipertensi stage II. Kateter vena sentral kemudian ditempatkan di vena femoralis kanan pasien. Pemeriksaan PCR juga dilakukan dua kali kepada pasien, dengan hasil positif.

Selama di ICU, pasien mendapat terapi levofloxacin $750 \mathrm{mg} / 24$ jam, dexamethason 5mg/8jam. N. Asetil sistein 200mg/8jam, omeprazole 40mg/12 jam, metoclopramid $10 \mathrm{mg} / 12 \mathrm{jam}$, zinc 1 tab $/ 24$ jam, amlodipin 5mg/24 jam, salbutamol $4 \mathrm{mg} / 8 \mathrm{jam}$. Pasien dilakukan nebulisasi dengan ventolin (1): flixotide (1) / 8jam. Untuk antikoagulan pasien mendapat unfractionated heparin (UFH) secara syringe pump dengan dosis bervariasi antara $500-1000 \mathrm{iu} / \mathrm{jam}$.

Kami merawat dan memantau pasien di ICU selama 14 hari, dengan melakukan monitoring perbaikan hasil laboratorium pasien (Tabel 1). Pada hari kedua terjadi kesalahan pengambilan darah vena untuk pemeriksaan blood gas analysis (BGA) sehingga tidak dapat dinilai. Pada hari kelima pasien merupakan kondisi terburuk gambaran BGA dinilai dengan $\mathrm{P} / \mathrm{F}$ ratio menunjukkan nilai 62 (ARDS berat). Meskipun secara klinis pasien masih terlihat baik dengan saturasi 98 dan RR 35 dengan pemberian $\mathrm{O} 2$ masker 15 lpm. Pada hari ke-12 di ICU sudah mulai tampak perbaikan dengan ditunjukkan hasil P/F ratio bernilai 200 . Selama perawatan di ICU sampai hari ke-12 pasien diberikan oksigen masker $15 \mathrm{lpm}$.

Pasien dikeluarkan dari ICU pada hari ke-14 setelah $\mathrm{P} / \mathrm{F}$ ratio menunjukkan nilai 300. Pasien keluar dari ICU dan pindah ke bangsal isolasi setelah menunjukkan perbaikan yang signifikan. Setelah keluar dari ICU dilakukan foto toraks evaluasi kembali terhadap pasien pada hari-18, dimana ditemukan gambaran pneumonia yang berkurang berkurang (Gambar 2).

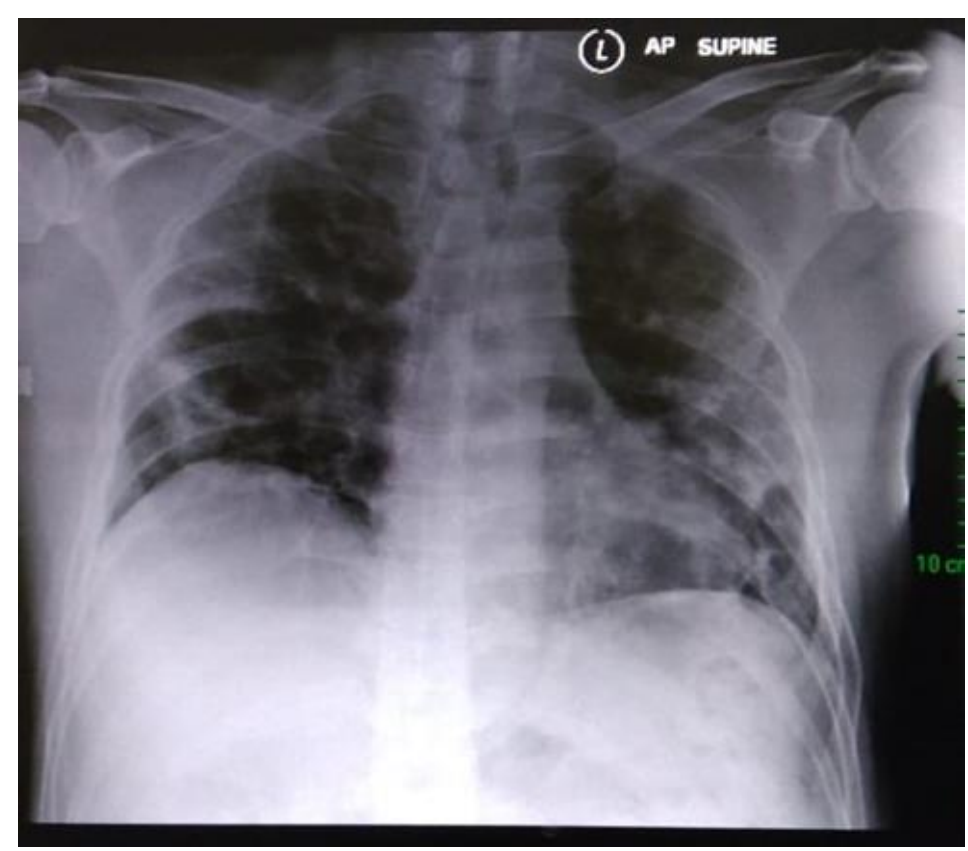

Gambar 2. X-foto toraks hari ke-18 
Tabel 1. Hasil laboratoratorium pasien selama di ICU

\begin{tabular}{|c|c|c|c|c|c|c|c|c|c|c|c|c|c|c|}
\hline Hari & 1 & 2 & 3 & 4 & 5 & 6 & 7 & 8 & 9 & 10 & 11 & 12 & 13 & 14 \\
\hline $\mathrm{pH}$ & 7,4 & 7,38 & 7,31 & 7,44 & 7,45 & 7,43 & 7,41 & 7,38 & 7,38 & 7,32 & 7,48 & 7,38 & 7,32 & 7,38 \\
\hline $\mathrm{FiO}_{2}$ & 80 & 80 & 80 & 80 & 80 & 80 & 69 & 61 & 60 & 60 & 68 & 80 & 68 & 60 \\
\hline $\mathrm{SaO}_{2}$ & 96 & 95 & 98 & 98 & 99 & 98 & 99 & 97 & 97 & 97 & 96 & 99 & 99 & 99 \\
\hline $\mathrm{PaO}_{2}$ & 77 & 40 & 101 & 50 & 121 & 118 & 138 & 87 & 82 & 86 & 71 & 137 & 120 & 189 \\
\hline $\mathrm{PCO}_{2}$ & 30 & 38 & 35 & 34 & 31 & 24 & 38 & 42 & 48 & 39 & 38 & 42 & 40 & 38 \\
\hline $\mathrm{AaDO}_{2}$ & 462 & 625 & 235 & 426 & 481 & 383 & 298 & 308 & 299 & 288 & 298 & 286 & 351 & 386 \\
\hline $\mathrm{P} / \mathrm{F}$ ratio & 96 & 50 & 185 & 126 & 62 & 115 & 122 & 198 & 185 & 186 & 195 & 200 & 222 & 306 \\
\hline $\begin{array}{l}\text { UFH } \\
\mathrm{iu} / \mathrm{jam}\end{array}$ & 500 & 750 & 750 & 1000 & 750 & 1000 & 1000 & 1000 & 1000 & 750 & 500 & 500 & 500 & Stop \\
\hline $\begin{array}{l}\text { D-Dimer } \\
\mathrm{ug} / \mathrm{dl}\end{array}$ & 4.84 & & & & & & & & & & & & 1.52 & \\
\hline aPTT & 28,4 & 21,6 & 25,1 & 25,5 & 44,1 & 38,2 & 40 & 59,3 & 48,2 & 30,1 & 38,2 & 43,3 & 25,9 & 23,1 \\
\hline aPTTK & 32,6 & 32,6 & 33,7 & 33,5 & 33,1 & 34,5 & 32,6 & 32,6 & 32,6 & 38,0 & 38,6 & 34,1 & 33,2 & 34,8 \\
\hline
\end{tabular}

Pada Tabel 1 tersebut dijelaskan bahwa pasien dirawat di ICU selama 14 hari. Pasien mendapat UFH dengan dosis bervariasi tergantung dengan kadar aPTT pasien. Penggunaan heparin tertinggi pada dosis $1000 \mathrm{iu} / \mathrm{jam}$. Penggunaan UFH tertinggi pada hari keempat hingga hari kesembilan perawatan ICU 


\section{PEMBAHASAN}

Kasus COVID-19 yang berat hingga menyebabkan kematian seringkali ditemukan komplikasi koagulopati dan koagulasi intravaskular diseminata (DIC). Pasien dengan infeksi COVID-19 yang progresif dan parah dengan ARDS ditemukan dengan tingkat $D$-Dimer dan fibrinogen yang sangat tinggi, yang berujung pada keadaan hiperkoagulasi. Di sisi lain, pasien COVID-19 yang sakit parah dan kritis dengan imobilisasi berkepanjangan juga berisiko tinggi mengalami tromboemboli vena (VTE) dan beberapa pasien yang memerlukan ventilasi mekanis mungkin dapat mengalami emboli paru akut (PE) atau trombosis vena dalam (DVT), bahkan tanpa adanya faktor risiko sebelumnya. Mortalitas tinggi kasus COVID-19 terjadi pada orang tua, diabetes, obese dan ARDS. $3,4,6,7$

Pola temuan yang paling khas pada pasien dengan COVID-19 dan koagulopati yaitu adanya peningkatan kadar D-Dimer. Secara khusus, D-Dimer yang sangat tinggi mencerminkan aktivasi koagulasi, perkembangan menjadi badai sitokin, dan disfungsi organ yang kemudian dikaitkan dengan angka perawatan intensif di ICU yang lebih tinggi hingga berujung pada kematian. Dipercaya bahwa kaskade koagulasi dalam COVID-19 teraktivasi melalui mekanisme seperti yang dijelaskan di atas, yang mengarah pada pembentukan trombin yang mengalami deregulasi baik secara sistemik maupun lokal di paru, mengakibatkan pengendapan fibrin yang pada akhirnya menyebabkan kerusakan jaringan dan mikroangiopati. Selain itu, SARS-CoV2 akan secara langsung merusak sel endotel vaskular melalui enzim pengubah angiotensin 2 (ACE2) di sel pneumosit tipe II, yang dapat memicu koagulasi abnormal khususnya di paru.
Dalam konteks ini, kontak yang ketat antara pneumosit tipe II dan jaringan pembuluh darah paru, dan reaksi inflamasi lokal yang parah, kemungkinan besar akan mendorong keadaan hiperkoagulasi paru umum yang terlihat pada pasien dengan COVID-19. Meski demikian, mekanisme yang berkontribusi pada koagulopati pada COVID-19 masih belum dapat dipastikan mengingat masih sedikit penelitian yang konklusif terhadap kasus ini. $^{3,4,8,9}$ Pada pasien ini ditemukan ARDS berat dengan Nilai D-Dimer tinggi yaitu 4,84 ug/dl.

Prinsip pengelolaan pasien COVID-19 yaitu mengurangi aktivitas mediator proinflamasi dan mencegah hiperkoagulasi yang tidak terkontrol, untuk menciptakan perbaikan kondisi pasien sebagai hasil akhirnya. Penggunaan antikoagulan untuk pasien COVID-19 telah direkomendasikan. Penggunaan antikogulan dapat menurunkan mortalitas pada pasien Covid 19. 5,10,11

Agen tromboprofilaksis yang tepat digunakan pada pasien dengan COVID19 hingga saat ini masih belum didukung oleh penelitian yang cukup sehingga belum dapat ditetapkan secara mutlak. Namun, penggunaan heparin, baik UFH maupun low molecular weight heparin (LMWH), dapat digunakan. Pemberian terapi antikoagulan didasarkan pada penilaian kondisi klinis pasien yang tepat yaitu antara risiko trombosis dan risiko perdarahan. Adanya koagulopati dan peningkatan kadar $D$-Dimer juga dapat digunakan sebagai pedoman dalam pengambilan keputusan untuk menggunakan dosis terapeutik. Dosis profilaksis heparin direkomendasikan untuk semua pasien COVID-19 yang dirawat di rumah sakit jika tidak ada kontraindikasi. Namun, dosis profilaksis standar mungkin tidak cukup pada pasien 
dengan kondisi yang parah dan kritis dengan risiko tromboemboli. Akan tetapi diperlukan monitoring sehingga tidak terjadi komplikasi. ${ }^{5,10,11}$

Kasus yang kami bahas sudah sejalan dengan pedoman yang disajikan di atas, di mana kami menggunakan variasi dari dosis profilaktik hingga dosis terapeutik (hingga 18 unit / kgBB / jam IV) secara syringe pump untuk pasien. Uji klinis terkontrol random yang mengevaluasi antikoagulasi dosis terapeutik empiris pada pasien dengan COVID-19 tanpa indikasi yang jelas (misalnya trombosis vena atau arteri, pencegahan stroke pada fibrilasi atrium, penggantian katup jantung) atau tanda klinis pembekuan saat ini masih belum konklusif. Sementara itu, banyak institusi yang menerapkan antikoagulasi dosis terapeutik empiris berdasarkan risiko VTE dan insiden perdarahan yang rendah secara keseluruhan $(3-5 \%) .{ }^{4,5,10-}$ 15

Penggunaan heparin dosis rendah dikaitkan dengan penurunan mortalitas dalam kurun waktu 28 hari pada sepsis yang cukup signifikan. Penelitian lain menunjukkan penurunan risiko kematian pada kisaran waktu 7 hingga 28 hari, dan peningkatan rasio $\mathrm{PaO}_{2} / \mathrm{FiO}_{2}$ yang signifikan pada pasien dengan ARDS yang mendapat terapi LMWH dosis tinggi. Penelitian ini juga menunjukkan bahwa pengobatan dengan heparin dapat membantu dalam mengurangi koagulopati paru yang ditemukan di ARDS ${ }^{10}$.

\section{KESIMPULAN}

Aktivasi koagulasi pada kasus COVID19 merupakan salah satu mekanisme yang mendasari perubahan patologis dan menentukan progresivitas penyakit yang secara spesifik melibatkan mikrovaskulatur paru, dan peningkatan risiko
DVT, PE, dan DIC pada fase berat hingga kritis. Penggunaan antikoagulan, dengan unfractionated heparin dengan dosis lebih tinggi, direkomendasikan untuk pasien dengan COVID-19 dengan ARDS berat, meskipun panduan akhir belum dapat diterapkan. Perlu lebih banyak uji klinis diperlukan untuk mengkonfirmasi hasil pengamatan dari kasus ini.

\section{DAFTAR PUSTAKA}

1. Coronavirus disease (COVID-19) World Health Organization [Internet]. [cited 2020 Dec 15]. Available from: https://www.who.int/emergencies/d iseases/novel-coronavirus-2019

2. Naming the coronavirus disease (COVID-19) and the virus that causes it [Internet]. [cited 2020 Dec 15]. Available from: https://www.who.int/emergencies/d iseases/novel-coronavirus2019/technical-guidance/namingthe-coronavirus-disease-(covid2019)-and-the-virus-that-causes-it

3. showPdf.pdf [Internet]. [cited 2020 Dec 15]. Available from: https://www.thelancet.com/action/s howPdf?pii=S23523026\%2820\%2930145-9

4. Kipshidze N, Dangas G, White CJ, Kipshidze N, Siddiqui F, Lattimer $\mathrm{CR}$, et al. Viral Coagulopathy in Patients With COVID-19: Treatment and Care. Clin Appl Thromb [Internet]. 2020 Jul 20;26. Available from: https://www.ncbi.nlm.nih.gov/pmc/ articles/PMC7461127/

5. Rico-Mesa JS, Rosas D, AhmadianTehrani A, White A, Anderson AS, Chilton R. The Role of Anticoagulation in COVID-19Induced Hypercoagulability. Curr Cardiol Rep [Internet]. 2020;22(7). Available 
https://www.ncbi.nlm.nih.gov/pmc/ articles/PMC7298694/

6. Clinical characteristics and day-90 outcomes of 4244 critically ill adults with COVID-19: a prospective cohort study. Intensive Care Med. 2020 Oct 29;1-14.

7. Al Heialy S, Yaseen Hachim M, Yaseen Hachim I, Bin Naeem K, Hannawi H, Al Salmi I, et al. Combination of obesity and comorbidities leads to unfavorable outcomes in COVID-19 patients. Saudi J Biol Sci [Internet]. 2020 Dec 3; Available from: https://www.ncbi.nlm.nih.gov/pmc/ articles/PMC7713568/

8. Coagulopathy is a major extrapulmonary risk factor for mortality in hospitalized patients with COVID-19 with type 2 diabetes | BMJ Open Diabetes Research \& Care [Internet]. [cited 2020 Dec 15]. Available from: https://drc.bmj.com/content/8/2/e00 1851.long

9. Kruse JM, Magomedov A, Kurreck A, Münch FH, Koerner R, KamhiehMilz J, et al. Thromboembolic complications in critically ill COVID-19 patients are associated with impaired fibrinolysis. Crit Care [Internet]. 2020 Dec 7;24. Available from:

https://www.ncbi.nlm.nih.gov/pmc/ articles/PMC7719734/

10. Tang N, Bai H, Chen X, Gong J, Li $\mathrm{D}$, Sun Z. Anticoagulant treatment is associated with decreased mortality in severe coronavirus disease 2019 patients with coagulopathy. J Thromb Haemost. 2020 May 1;18(5):1094-9
11. Ayerbe L, Risco C, Ayis S. The association between treatment with heparin and survival in patients with Covid-19. J Thromb Thrombolysis. 2020 May 31;1-4

12. Boonyawat K, Chantrathammachart $P$, Numthavej $P$, Nanthatanti $N$, Phusanti S, Phuphuakrat A, et al. Incidence of thromboembolism in patients with COVID-19: a systematic review and metaanalysis. Thromb J [Internet]. 2020 Nov 23;18. Available from: https://www.ncbi.nlm.nih.gov/pmc/ articles/PMC7680990/

13. Hamadé A, Jambert L, Tousch J, Talbot M, Dervieux B, Nazer TE, et al. Systematic Duplex Ultrasound Screening in Conventional Units for COVID-19 Patients with Follow-up of 5 Days. J Vasc Surg Venous Lymphat Disord [Internet]. 2020 Dec 2; Available from: https://www.ncbi.nlm.nih.gov/pmc/ articles/PMC7709786/

14. Avula A, Nalleballe K, Toom S, Siddamreddy S, Gurala D, Katyal N, et al. Incidence of Thrombotic Events and Outcomes in COVID-19 Patients Admitted to Intensive Care Units. Cureus [Internet]. 12(10). Available from: https://www.ncbi.nlm.nih.gov/pmc/ articles/PMC7678760/

15. 15. Canoglu Kadir, Saylan Bengu. Therapeutic dosing of lowmolecular-weight heparin may decrease mortality in patients with severe COVID-19 infection. Ann Saudi Med. 2020 Nov 1;40(6):4628 